\title{
Exploring Future Teachers' Awareness, Competence, Confidence, and Attitudes Regarding Teaching Online: Incorporating Blended/Online Experience into the Teaching and Learning in Higher Education Course for Graduate Students
}

Suzanne Le-May Sheffield, Jill Marie McSweeney, and Aaron Panych Dalhousie University

\begin{abstract}
Dalhousie University's Centre for Learning and Teaching offers a Certificate in University Teaching and Learning, which includes a 12-week course entitled Teaching and Learning in Higher Education. This course provides the certificate's theory component and has evolved to reflect the changing needs of future educators. One significant change is the development of a blended course model that incorporates graded online facilitation, prompted by the recognition that teaching assistants and faculty are increasingly required to teach online or blended (i.e., combining face-to-face and online) courses. This study invited graduate students enrolled in the course to participate in pre- and post-facilitation questionnaires that assessed their awareness, competence, confidence, and attitudes towards online and blended learning. Students recognized the value of the online component for future teaching expertise and experienced increased awareness, competence, and confidence regarding teaching online. However, preference for face-to-face teaching and student learning did not change.
\end{abstract}




\section{Résumé}

Le Centre for Learning and Teaching de l'Université Dalhousie offre un certificat en pédagogie de l'enseignement universitaire, lequel comprend un cours de douze semaines intitulé « Teaching and Learning in Higher Education ». Au fil du temps, ce cours théorique a évolué pour s'adapter aux besoins des futurs pédagogues. En outre, parce que les assistants à l'enseignement et les membres de la faculté sont sollicités de plus en plus fréquemment pour donner des cours en ligne ou hybrides (combinant l'enseignement en classe et à distance), on a intégré un modèle de cours hybride facilitant la correction de travaux. C'est ainsi qu'on a invité des étudiants des cycles supérieurs à remplir un questionnaire avant de suivre le cours et après l'avoir suivi. Ce questionnaire évaluait leurs connaissances, compétences et attitudes par rapport à l'enseignement en ligne et hybride. Les étudiants ont reconnu l'importance de l'enseignement en ligne dans leur formation. Ils ont démontré une plus grande connaissance des approches d'enseignement et ont rapporté avoir une meilleure confiance en eux relativement à l'enseignement en ligne. Néanmoins, leur préférence pour l'enseignement en classe n’a pas changé.

\section{How the Project Began}

In 2012, a guest speaker in the Teaching and Learning in Higher Education course (CNLT 5000) left the graduate students with an important message: Whether they liked it or not, teaching online was unlikely to be an option or an add-on to their teaching careers, as it had been for his career. All of them, at one point or another, would be required to teach online. This was a pivotal moment for me (Suzanne). As the instructor for the course, I recognized that I was doing students a disservice by not incorporating technology as a more integral component of the course, especially as some of the students in the class were already working in the online environment as teaching assistants. I realized it was no longer enough to just provide a Technology Week within the framework of the course; rather, it needed to be a fully integrated component.

While colleagues suggested to me that such a goal could/should be a separate course, I reflected that those who would take a course about teaching online would be the already converted. CNLT 5000 was an excellent opportunity to introduce students to the idea of teaching online and to provide them with practical experience. My own attitudes towards teaching with technology have always been cautious, and I reflected that over time, my students seemed to collectively share my preference for face-to-face learning and teaching. Incorporating an online component within CNLT 5000 would allow me to include the technology naysayers in this journey-a rare opportunity for educational developers, whose self-selected audience is often open and receptive.

In 2013, I created the online assignment outlined in this article. All students experienced creating an online exercise as an "instructor" and played a role as "students" in their peers' online activities. In this way, the CNLT 5000 course became a blended course, and students experienced both the teaching and the learning sides of the online environment.

During week 11 of the 12-week course, I continued my practice of inviting guest speakers to present on their own online and blended teaching experiences-but now, the stu- 
dents came to this week's class having spent a good part of the course teaching and learning in an online environment. After the guest speakers gave their presentations, I asked the students to work in groups to consider how they would adapt the face-to-face course they had been creating as part of CNLT 5000 to an online course. Previously, students had been resistant, and I thought that a course-long consideration of such an option would make them more open to it. However, this did not prove to be the case.

Students remained persistently attached to their preference for the face-to-face teaching and learning environment; they were sure their courses could not possibly work as well, or that they could not even be redesigned for the online environment. However, the anecdotal feedback I received suggested that they had become more aware, confident, and competent with teaching and learning in the online environment. It was this experience that led me to create the following study during the 2014 iteration of the course, in order to determine whether my own perceptions of students' teaching experiences and attitudes about online and blended learning environments could be confirmed.

\section{Introduction}

The Centre for Learning and Teaching (CLT) at Dalhousie University offers a Certificate in University Teaching and Learning (CUTL) for all graduate students. The main objective of this voluntary program is to assist students in preparing for their teaching responsibilities as teaching assistants and future faculty. More specifically, the program enables graduate students to (i) acquire a comprehensive set of teaching skills, (ii) engage in reflective teaching practice and receive feedback from experienced faculty about their teaching in a disciplinary context, and (iii) make connections with peers across campus to create a broader and deeper understanding of academic life.

One of the four components of the CUTL is a 12-week course entitled Teaching and Learning in Higher Education (CNLT 5000). It is a non-credit, pass/fail graduate course that appears on a student's university transcript. This course fulfills the theory component of the program and has evolved over time to reflect the changing needs of higher education educators. One significant change has been the growth of an online component. Over the past six iterations of the course, the instructor dedicated one week of a 12-week course to talking about technology. Over the last couple of years, an integrated online presence for the course has been created, and a graded opportunity for students to participate in teaching their peers through online discussions and activities has been developed.

As more students seek online courses, ever-increasing numbers of faculty are required to teach online or within a blended (i.e., thoughtful integration of face-to-face and online components) environment (Allen \& Seaman, 2011, 2013). Yet in their most recent study of online education, Allen and Seaman (2013) noted that institutions' chief academic officers have reported an overall decrease in faculty acceptance of the legitimacy of online learning since 2004. Power and Gould-Morven (2011) noted that "online learning seems paradoxically to be both booming and busting simultaneously" (p. 19). Faculty have proven resistant to online teaching and learning, in part because they believe that their educational culture and values are threatened by this change. Concerns about online teaching also include increasing workloads, lack of resources, compensation and intellectual property issues, inadequate technological skills and training, anxiety about or lack of confidence with technology, and pedagogical concerns for the effectiveness of student 
learning in the online environment (Bennett \& Lockyer, 2004; Hunt, Davies, Richardson, Hammock, Akins, \& Russ, 2014; Johnson, Wisniewski, Kuhlemeyer, Isaacs, \& Krzykowski, 2012; Power \& Gould-Morven, 2011). These concerns are heightened for faculty with little or no experience with online teaching (Herman, 2012; Hunt et al., 2014).

Despite increasing demand for this approach and evidence that online learning can be as effective as face-to-face (Hawkins, Graham, \& Barbour, 2012; King, 2002), the literature underscores that faculty often do not receive the requisite preparation to teach online, continue to prefer face-to-face teaching, and hold a variety of negative opinions about online teaching and learning, although this may vary to different extents depending on the type of institution (Power \& Gould-Morven, 2011; Windes \& Lesht, 2014). Teachers acclimatized to the face-to-face classroom report feeling disconnected from students and colleagues in the virtual classroom and believe their students feel isolated and disconnected (Hawkins et al., 2012; Power \& Gould-Morven, 2011).

To ensure faculty buy-in and ability, a number of authors have argued that early career faculty need to be made aware of approaches to, and competencies necessary for, online and blended teaching and learning, and they need to understand how to design a course space using a learning management system (LMS) interface (Hixon, Barczyk, Buckenmeyer, \& Feldman, 2011; Lane, 2013). In addition, it is recommended that they: (i) be provided with opportunities to consider their own teaching styles and roles in the online context; (ii) realize that they need to create collaborative, student-centred learning approaches; and (iii) learn how to develop an online presence, rapport, and sense of community to ensure successful learning (Bennett \& Lockyer, 2004; Bigatel, Ragan, Kennan, May, \& Redmond, 2012; Garrison, 2009; Hawkins et al., 2012; King, 2002; McQuiggan, 2012).

Increased institutional support for online faculty development programs is important (Herman, 2012; Hixon et al., 2011). Moreover, the nature of such learning through professional development opportunities is equally critical and should be grounded in effective pedagogical approaches (not just learning the tools), include hands-on, team (peer) learning/mentoring with ongoing face-to-face technological and design support, and offer immediate application to real-world teaching and learning contexts (Baran \& Correia, 2014; Baran, Correia, \& Thompson, 2011; Herman, 2012; Myer \& Murrell, 2014; Salmon \& Wright, 2014). Lane (2013) has argued for the value in learning to teach online in an open web course, in order to obtain first-hand experience and receive a "deeper preparation for teaching online through an authentic experience in the online environment" (p. 3); she further highlighted the significance of providing graduate students and new faculty with the experience of teaching and learning in online and blended environments.

Finally, faculty need to be supported to change their cultural values around learning. This includes acknowledging fears, highlighting the rewards, developing objective data about online learning, offering online learning experiences, and providing on-going support (Mitchell, Parlamis, \& Claiborne, 2015). Early introduction to online teaching contexts should provide early career faculty with improved knowledge and skill sets and may improve their comfort level with, and attitudes towards, online and blended learning (Baran et al., 2011; McQuiggan, 2007, 2012). Moreover, McQuiggan (2007, 2012) has pointed out that teachers' learning experiences in the online environment can subsequently inform their future face-to-face teaching. 
To our knowledge, no research has assessed the awareness, competence, confidence, and attitudes of future faculty or teaching assistants towards online and blended teaching. This gap in the literature suggests that few graduate students get the opportunity to explore this facet of teaching as an instructor, although certainly some may experience online learning as students. In a 2014 article, "Exploring the Context of Canadian Graduate Student Teaching Certificates in University Teaching," Kenny, Watson, and Watton made no mention of online teaching as a component of these certificates, although they did point to the opportunity for more flexible learning for participants through the use of blended and online modes. Calonge, Chiu, Thadani, Mark, and Pun (2011) discussed the use of a blended mode for a graduate course, Teaching Students: First Steps, at the City University of Hong Kong. In this course, the instructors set up online student-led discussions, where part of the goal was to assist students in experiencing active learning in various ways in order to change students' view of authority. Ideally, graduate students in a certificate program in university teaching and learning ought to be given the chance to understand the technology and dynamics of teaching in an online environment, just as they are encouraged to learn about a variety of aspects of face-to-face teaching.

This article explores the impact of offering graduate students and future faculty the opportunity to experience both teaching and learning in an online and blended environment. The aim of this study was to determine whether integrating an online teaching exercise into a teaching and learning course enhanced students' awareness, competence, confidence, and attitudes with respect to online and blended learning.

\section{Method}

\section{Participants and Procedure}

Students enrolled in Teaching and Learning in Higher Education (CNLT 5000), a core component of the CUTL Program at Dalhousie University, were recruited to participate in an online, two-part, research ethics approved study about their awareness, competence, confidence, and attitudes with respect to teaching and learning in online and blended environments. Participants filled out an online survey during the second week (the pre-facilitation survey) and at the end (the post-facilitation survey) of the course. ${ }^{1}$ Students who did not participate in the first survey were still eligible and invited to participate in the second survey.

Online facilitation exercise. All students enrolled in the course participated in weekly student-led online facilitations that allowed them to design a mini course site. This assessment was worth $15 \%$ of their overall workload. The goal was to enable students to develop an understanding of online teaching and learning through conducting and participating in the online facilitation. Students chose which topic and week to facilitate; they were then required to provide readings and a summary and to create an interactive exercise that promoted student engagement around that week's topic. To encourage students to understand the need for, and benefit of, seeking instructional design assistance, students received an in-class introduction to using the university's LMS, and each group had a mandatory consultation with an instructional designer from the CLT. At the end of each week, students gave a short (10-minute) presentation or held an in-class discussion about their topic. Most groups reflected upon their experiences so that subsequent groups could learn 
from and build upon their successes and challenges. Using a rubric that students designed at the outset of the course, each group's facilitation was graded by their peers.

Pre-facilitation survey. The pre-facilitation survey asked about: previous experiences as learners and teachers in online and blended courses; participants' comfort level with navigating in an LMS; and interacting with material, instructors, and other students in online learning environments. Participants were also asked (i) whether online and blended environments facilitated or inhibited their learning and teaching, (ii) about their preferred learning and teaching environments, and (iii) what environments they believed were most effective. Finally, participants were asked to consider their upcoming online facilitation exercise in the course and whether they thought their teaching styles would change in an online environment, whether this environment would enhance their learning as students, and how they felt about facilitating the online activity. Closed-ended questions used either a four-point Likert scale ( $1=$ extremely uncomfortable to $4=$ extremely comfortable) or multiple-choice responses (e.g., yes, no, either, neither).

Post-facilitation survey. These questions used the same Likert-scale and multiplechoice responses as the pre-facilitation survey. Participants were asked about their experiences navigating and interacting in the online environment as students and teachers, the usefulness of classroom instruction, the value of consulting with an instructional designer, their preferred learning and teaching environments, and the formats they believed to be most effective for teaching and learning.

\section{Results}

\section{Demographic Data}

Forty-two students were registered for CNLT 5000 and eligible to participate in both surveys. A total of 21 (50\%) and 20 (48\%) students completed the pre- and post-facilitation surveys. Due to the small class size, demographic data (e.g., age, gender) were not requested, to ensure anonymity. However, the class consisted of a variety of master's students, doctoral students, and post-doctoral fellows, representing eight of Dalhousie University's 12 faculties. Participants also reported on what technologies they used on a regular basis for both school and social activities, such as Internet surfing, social media, email, texting, course-related LMS use, research-related searches, and reading documents. There were no reports of excessive use of any one particular device or program and no changes in use between pre- and post-facilitation survey responses.

\section{Pre-Facilitation Survey Results}

Experience with online teaching and learning. Sixty-seven percent $(n=14)$ and $72 \%(n=15)$ of participants had taken a fully online or blended course, respectively. Of those, all reported feeling either very comfortable or extremely comfortable with navigating the LMS and interacting with online material, and all felt that experience and time with the online environment made it easier to navigate. For example, one participant wrote that "long term use made it comfortable," while another said, "Once I figured out how [the LMS system] worked it was easy enough to access the content, but it took a little while to get used to." Although the majority of participants reported feeling very comfortable interacting online, there had often been little expectation to do so. One participant 
explained, "[There] wasn't a lot of interaction," and another wrote, "[N]ot many students chose to actually participate." In the blended context, a few comments suggested that "face-to-face interaction with [the] instructor is more efficient."

Participants had much more limited experience teaching online. Only one person had been an instructor/TA for a fully online course, while $33 \%(n=7)$ had been an instructor/ TA for a blended one. Most had received no LMS training or instruction about creating an online teaching presence. Despite this fact, $19 \%(n=4)$ felt very comfortable teaching online, although several indicated (i) that this was because it was a blended course, (ii) they were not interacting with students and only uploading marks and downloading materials, or (iii) that although they were comfortable, "students rarely used it."

Anticipating teaching and learning online in CNLT 500o. Fifty-two percent ( $n=11$ ) of participants felt that having the experience of blended learning in CNLT 5000 would help their teaching, while 33\% $(n=7)$ were unsure, and $14 \%(n=3)$ said it would not. Some thought that the flexibility, ongoing learning, and "more opportunity to learn" of the online environment enhanced their learning, while others noted that it resulted in distraction, more work, and difficulty with communication. Students were almost unanimous $(86 \%, n=18)$ that their experiences with facilitating an online activity would necessitate changing their teaching styles, and they raised concerns of communication challenges and limitations in online environments that do not exist face-to-face. When asked how they felt about participating in the online facilitation, $48 \%(n=10)$ felt challenged, $38 \%(n=8)$ excited, 33\% $(n=7)$ happy, and 29\% $(n=6)$ nervous. When asked why, participants said it was due to their lack of experience $(n=8)$ and that they were unsure how it would turn out $(n=4)$, but that it was a good experience nonetheless $(n=7)$. A participant explained, "On one hand, I feel slightly nervous since [I've] never had to teach online; on the other hand, this is a good challenge." Another commented, "I think it will be a useful skill, and the stakes seem low. This seems like an ideal learning opportunity."

Attitudes and beliefs about learning in an online and blended environment. Participants largely felt that they would prefer to learn in a blended environment $(43 \%, n=9)$, compared to $29 \%(n=6)$ who preferred face-to-face. No one answered that they would prefer to learn in a fully online environment. Participants believed learning was more effective in a blended environment $(62 \%, n=13)$ compared to face-to-face $(33 \%, n=7)$ and online $(5 \%, n=1)$ environments, and that teaching was more effective in either a face-to-face $(52 \%, n=11)$ or blended $(38 \%, n=8)$ environment. None of the participants thought teaching was more effective in a purely online environment.

\section{Post-Facilitation Survey Results}

Experiencing learning online in CNLT 5000. When asked whether they felt that the blended environment facilitated their learning in CNLT 5000, 55\% $(n=11)$ responded yes, $15 \%(n=3)$ said no, and 30\% $(n=6)$ said neither. Participants noted that the online learning between face-to-face classes in CNLT 5000 helped with understanding concepts, allowed for participation at a convenient pace and time, increased interactions with others, and helped them prepare for class. Although no one thought that the blended CNLT 5000 course inhibited their learning, participants did emphasize that it did not provide a substitute for face-to-face learning. One participant reported that "online is additive only," another said that "nothing replaces the face-to-face," and one felt that "face-to- 
face learning is required and [one] should only use online learning as an accessory to the course, and not go completely 'online."”

Eighty-five percent $(n=17)$ of participants felt extremely or very comfortable navigating the LMS. A smaller number $(n=6)$ felt that the facilitation activity made them more comfortable; they reported: "It was awkward at first, but after the first couple weeks it became pretty easy"; "Having developed an online environment made navigating others much easier"; and "The course helped me understand BBL [Dalhousie's LMS-Blackboard Learn] and its capabilities. I am not afraid!" Almost all participants felt extremely or very comfortable interacting with material $(90 \%, n=18)$ and students (95\%, $n=19)$ online, explaining that "it's easier than interacting in person at times, since you have more time to think," and "[p]eople pay more attention to what you are saying [online] (and also respond more to it)."

Experiencing support for online teaching. As part of the course, students received a lecture from an online instructional designer on developing an online presence as a teacher and were required to meet as a group with him to discuss their facilitation plans. Overall, participants found that the presentation $(80 \%, n=16)$ and one-on-one experience $(85 \%, n=17)$ were critical in preparing them for their facilitation activity. Participants explained that "meeting was the most helpful . . . as it set us on track with what we were going to do," "I had not thought about teacher presence in those terms prior to the course," and that without this one-on-one meeting, "we would have either spent a lot of time on designing the page, thus having less time to design the activity, or [would have] stay[ed] with something very basic." Participants felt comfortable designing online content (80\%, $n$ = 16), noting that "when what we want is clear in our mind, it can be very easy to be done," and "I now have the foundational knowledge to prepare a basic learning system."

\section{Reflections from an online instructional designer.}

Looking back, the group online activities and the face-to-face preparation with the students stand out. I (Aaron) enjoyed meeting them individually, and it was interesting to discuss the approaches they wanted to take with their facilitation, as it provided me with closer personal contact with students.

We discussed different ways group themes and outcomes could integrate with the LMS, and I did a quick mock-up demonstration of what their group's activity would look like online. It was a new opportunity for students to talk about a pedagogical problem and explore the various online tools that could offer a solution. Students were enthusiastic about the online exercise, and it was gratifying to see that they appreciated and benefited from the instructional design assistance. I believe this speaks to the need for instructor support for educational technologies. In hindsight, it would have been great to have had post-activity meetings with the groups to discuss what worked and what didn't, and what potential solutions are out there for their problems.

It was interesting to see the preference for blended learning in the post-facilitation survey, a preference that is consistent with a larger campus-wide survey on online learning. It tells me students see that both face-to-face and online settings have their effective uses for teaching and learning. 
Experiencing teaching online in CNLT 500o. Sixty-five percent $(n=13)$ felt the facilitation activity enhanced their ability to teach online, while 10\% $(n=2)$ said it did not help, and 20\% $(n=4)$ said it neither did nor did not help. Participants noted: "It certainly helped me to understand [the LMS], and how to facilitate online discussion"; "It certainly taught me that there is much more to online courses than [I] initially thought"; and "It allowed me to see what was going to be problematic for when I create an online course in the future."

When asked how they felt about the opportunity to teach online through the facilitation activity, 65\% $(n=13)$ said challenged, while 40\% $(n=8)$ and 35\% $(n=7)$ felt excited and happy, explaining: "It is [a] completely new experience. So I felt excited to learn, felt challenged when I struggled to figure out something, and was happy when I learned a new thing"; "[I'm] happy and excited [that] I could try another way to learn. [I was] challenged [with] how and what I could do to help [make] others' learning more comfortable"; and "It was a time-consuming project, but I felt like I learned a lot from it."

While in the pre-facilitation survey almost all participants thought their teaching style would change for online teaching, the post-facilitation survey resulted in a mixed response, with $45 \%(n=9)$ saying that their teaching style changed and $20 \%(n=4)$ saying it did not. Participants noted that the online environment did not allow for demos, was more structured, and that "it's much harder to communicate nuance in the online environment-things like excitement [and] humour . . . are lost."

Attitudes and beliefs about teaching and learning in an online and blended environment. Given the choice, $95 \%(n=19)$ preferred to learn face-to-face or blended, while no one chose online only. The blended environment was considered useful, as it "helps students to prepare their lectures well and get engagement" and still provides students with "direct interaction," "immediate answers," and "in person and in group discussion" through the face-to-face environment. When asked where they believe learning is more effective, 60\% $(n=12)$ said a blended environment, 30\% $(n=6)$ picked face-toface, and none chose fully online. Participants explained that the ability for face-to-face communication (25\%, $n=5$ ) was important for learning, but some noted that "blended courses offer the opportunity to engage with the material in a variety of fashions and at various time[s]," and "As a learner I can take advantage of different strengths of these formats-they reinforce one another, and can lead to deeper understanding of the material."

Overall, participants reported that they would prefer to teach face-to-face $(50 \%, n=$ $10)$ or in a blended environment $(45 \%, n=9)$, while none would choose fully online. When asked where teaching is most effective, 55\% $(n=11)$ said a blended environment, 30\% $(n=$ 6) face-to-face, and no one said fully online. While participants preferred face-to-face teaching, they recognized the value of blended courses to effective teaching. One participant said, "My teaching style requires me to interact with the classroom setting in a dynamic way ... I appreciate that online learning may be optimum for other fields of studies or teaching approaches," while another person wrote, "It's an online world baby. Get in the conversation."

\section{Discussion and Conclusions}

Our study demonstrates that the trepidation faculty members express about online teaching and their negative opinions about online learning, as outlined in the literature (Bennett \& Lockyer, 2004; Herman, 2012; Hunt et al., 2014; Johnson et al., 2012), can also be found in graduate students/future teachers who may lack experience as students 
or educators in online learning environments. Lack of training opportunities and experience with learning and teaching online, as well as beliefs about the ineffectiveness of online learning in comparison with face-to-face learning, play a role in creating feelings of apprehension about teaching online and in fostering a preference for teaching and learning in the classroom. However, this study suggests that given the opportunity to learn, with support and experience gained through online training, a peer-team learning environment, hands-on LMS design, and first-hand online teaching and learning experience, graduate students and future faculty can gain awareness, competence, and confidence regarding both learning and teaching in the online environment.

Graduate students/future teachers also demonstrated a shift in their attitude towards online learning. An increase in the belief of the value and possibilities of blended learning between pre- and post-facilitation surveys indicates that experiencing a blended course opened participants to the possible benefits in pairing online learning opportunities with face-to-face classroom experiences. Despite this shift, however, participants continued to favour the inclusion of some face-to-face learning and teaching and expressed an aversion for completely online courses. Thus if graduate students/future teachers experienced a fully online teaching and learning course, they may also have an increased belief in the value of teaching and learning in that context. The results of this current study suggest fertile ground for future research about how positive attitudes towards fully online teaching and learning could be fostered in graduate student TAs and future teachers.

While this research is based on one graduate course and a small sample of graduate students/future teachers, it nevertheless suggests that providing graduate students/ future teachers with training and experience in online teaching could be of great importance to the future of teaching and learning in a world dominated by increasing numbers of online courses (Allen \& Seaman, 2011, 2013). The role of educational developers and instructional designers in preparing graduate students/future teachers to teach online is pivotal. We need to prepare TAs and future teachers to design effective online learning environments, increase their knowledge of online teaching and learning, and engage in ways to create an online presence so they can build their competence and confidence in this area. More experience of blended and online learning environments could provide opportunities for graduate students/future teachers to shift their attitudes about online learning. One goal for educational developers and instructional designers should be to support, train, and teach graduate students/future teachers to see face-to-face, blended, and online teaching and learning on a spectrum of equally effective approaches available to learners and teachers, meeting different needs in different contexts.

\section{Post-Survey Reflections}

In 2013 and 2014, students voiced frustration in class with their ability to learn how to work with the LMS, the time-consuming, 24/7 expectations of teaching and learning online, and their continued preference for face-to-face learning and teaching. During Technology Week in 2014, I (Suzanne) was asked, rhetorically, whether I would consider teaching CNLT 5000 as a fully online course. When I paused in thought, the student looked aghast and expressed concern that I would even consider doing so, and the student's classmates agreed emphatically. Despite students' experiences with the online community developed as a class, they believed that it wouldn't have been possible without the face-to-face interaction. 
My own journey over the previous three years had led me to change my perspective. While I still preferred to teach face-to-face, I saw the possibilities and the advantages to teaching online and blended courses. Several facts were clear online and in class: the asynchronous mode of participation allowed for time to think before responding; thoughtful exchanges resulted; there was a visible increase in students' participation in discussions about teaching and learning; and second-language learners and quieter students were more vocal online. These discussions bled over into classroom discussion. It was as if we were engaging together all week instead of for only three hours a week in class. From an immersive perspective, this was great, although students complained about the time commitment. I must say that at times, I found the commitment to continually check in to the site onerous, but the experience was enjoyable once I was online. I always entered the site with anticipation: What would the students create this week? How would others respond? What kinds of thoughts and discussions would arise?

This project has given me new perspectives on the scholarship of teaching and learning. As an educational developer engaging in a research project, I was conscious of my desire to obtain a good response rate for the surveys and of how this fact, and my own online participation as the instructor every week, might be affecting students' feelings and attitudes towards online teaching and learning. I wondered how students' awareness of the research project running parallel with the course was influencing their feelings and attitudes towards the course. Given the strong feedback I received first-hand about students' preference for not teaching online and preferring to teach face-to-face, I was surprised at the more tentative, neutral, or matter-of-fact nature of the qualitative comments in the survey. Students in the 2014 class did not express their feelings and attitudes as strongly in the survey as they did in person. It was as if their face-to-face communications meant more to them than filling in an online form. They did not engage with the online questionnaire in the same way they engaged in meaningful face-to-face dialogue with me and with their other classmates. I recognize the irony that this result reflects: the students' general preference for face-to-face, rather than online, interaction. As the 2015 iteration of the course has just concluded, I would further reflect that while some students incorporated an online aspect into their course design project and included references to online learning in their self-assessment, a significant number did not. Next year, I will ask students to specifically comment upon how they might incorporate online learning into their faceto-face course and to reflect upon how their course design might need to change if it was a fully online course. My hope would be that encouragement to think about these issues through written reflection, as well as in-class discussion and the design and participation experience, would play a role in TA/graduate student/future teachers' openness to the possibilities of online learning.

Despite ongoing challenges, I believe strongly in the learning process I have designed, and I will continue to work to foster positive attitudes towards blended and online learning and teaching. I believe in the value of this integrated model, in which all students who take CNLT 5000 (admittedly an already self-selected group interested in teaching and learning, for the most part) are introduced to the possibilities of blended and online teaching and learning. In this way, they can begin to see this kind of teaching as an integral part of their lives as teachers in the future. 


\section{Note}

1. Copies of the survey instruments are available upon request by emailing the primary author.

\section{References}

Allen, I. E., \& Seaman, J. (2011). Going the distance: Online education in the United States, 2011. Needham, MA: Sloan Consortium. Retrieved from http://www. onlinelearningsurvey.com/reports/goingthedistance.pdf

Allen, I. E., \& Seaman, J. (2013). Changing course: Ten years of tracking online education in the United States. Babson Park, MA: Babson Survey Research Group and Quahog Research Group. Retrieved from http://www.onlinelearningsurvey.com/reports/ changingcourse.pdf

Baran, E., \& Correia, A. (2014). A professional development framework for online teaching. TechTrends, 58(5), 96-102.

Baran, E., Correia, A., \& Thompson, A. (2011). Transforming online teaching practice: Critical analysis of the literature on the roles and competencies of online teachers. Distance Education, 32(3), 421-439.

Bennett, S., \& Lockyer, L. (2004). Becoming an online teacher: Adapting to a changed environment for teaching and learning in higher education. Educational Media International, 41(3), 231-248.

Bigatel, P. M., Ragan, L. C., Kennan, S., May, J., \& Redmond, B. F. (2012). The identification of competencies for online teaching success. Journal of Asynchronous Learning Networks, 16(1), 59-78.

Calonge, D. S., Chiu, P., Thadani, D. R, Mark, K. P., \& Pun, C. F. K. (2011). Inservice development for graduate teaching assistants: A blended-learning and formative approach. Journal of University Teaching \& Learning Practice, 8(3). Retrieved from http://ro.uow.edu.au/cgi/viewcontent.cgi?article=1216\&context=jutlp

Garrison, D. R. (2009). Implications of online learning for the conceptual development and practice of distance education. Journal of Distance Education, 23(2), 93-104.

Hawkins, A., Graham, C. R., \& Barbour, M. K. (2012). "Everybody is their own island": Teacher disconnection in a virtual school. The International Review of Research in Open and Distance Learning, 13(2), 123-144.

Herman, J. H. (2012). Faculty development programs: The frequency and variety of professional development programs available to online instructors. Journal of Asynchronous Learning Networks, 16(5), 87-106.

Hixon, E., Barczyk, C., Buckenmeyer, J., \& Feldman, L. (2011). Mentoring university faculty to become high quality online educators: A program evaluation. Online Journal of Distance Learning Administration, 14(4). Retrieved from http://www.westga. edu/ distance/ojdla/winter144/hixon_Barczyk_Buckenmeyer_feldman144.html 
Hunt, H. D., Davies, K., Richardson, D., Hammock, G., Akins, M., \& Russ, L. (2014). It is (more) about the students: Faculty motivations and concerns regarding teaching online. Online Journal of Distance Learning Administration, 17(2). Retrieved from http:// www.westga.edu/ distance/ojdla/summer172/Hunt_Davies_Richardson_Hammock_ Akins_Russ172.html

Johnson, T., Wisniewski, M. A., Kuhlemeyer, G., Isaacs, G., \& Krzykowski, J. (2012). Technology adoption in higher education: Overcoming anxiety through faculty bootcamp. Journal of Asynchronous Learning Networks, 16(2), 63-71.

Kenny, N., Watson, G. P., \& Watton, C. (2014). Exploring the context of Canadian graduate student teaching certificates in university teaching. Canadian Journal of Higher Education, 44(3), 1-19.

King, K. P. (2002). Identifying success in online teacher education and professional development. The Internet and Higher Education, 5, 231-246.

Lane, L. (2013). An open, online class to prepare faculty to teach online. Journal of Online Educators,1O(1). Retrieved from http://thejeo.com/Archives/Volume1oNumber1/ Lane.pdf

McQuiggan, C. A. (2007). The role of faculty development in online teaching's potential to question teaching beliefs and assumptions. Online Journal of Distance Learning Administration, $10(3)$. Retrieved from http://www.westga.edu/ distance/ojdla/fall103/ mcquiggan103.htm

McQuiggan, C. A. (2012). Faculty development for online teaching as a catalyst for change. Journal of Asynchronous Learning Networks, 16(2), 27-61.

Meyer, K. A., \& Murrell, V. S. (2014). A national study of training content and activities for faculty development for online teaching. Journal of Asynchronous Learning Networks, 18(1). Retrieved from http://olj.onlinelearningconsortium.org/index.php/olj/ article/view/355/97

Mitchell, L. D., Parlamis, J. D., \& Claiborne, S. A. (2015). Overcoming faculty avoidance of online education: From resistance to active participation. Journal of Management Education, 39(3), 350-371.

Power, M., \& Gould-Morven, A. (2011). Head of gold, feet of clay: The online learning paradox. International Review of Research in Open and Distance Learning, 12(2), 1939. Retrieved from http://www.irrodl.org/index.php/irrodl/article/view/916/1739

Salmon, G., \& Wright, P. (2014). Transforming future teaching through "Carpe Diem" learning design. Education Sciences, 4(1), 52-63.

Windes, D. L., \& Lesht, F. L. (2014). The effects of online teaching experience and institution type on faculty perceptions of teaching online. Online Journal of Distance Learning Administration, 17(1). Retrieved from http://www.westga.edu/ distance/ ojdla/spring171/windes_lesht171.html 


\section{Contact Information}

Suzanne Le-May Sheffield

Centre for Learning and Teaching

Dalhousie University

Suzanne.Sheffield@dal.ca

Dr. Suzanne Le-May Sheffield is the director of the Centre for Learning and Teaching at Dalhousie University, Nova Scotia, managing the centre's daily operations and ongoing program development. She has long had an interest in graduate student development, including co-creating the Certificate in University Learning and Teaching.

Jill Marie McSweeney works as an educational developer at the Centre for Learning and Teaching at Dalhousie University, with a focus on graduate student teaching and learning development. She is currently completing her $\mathrm{PhD}$ in interdisciplinary studies, looking at the integration of nature in learning environments and its influence on students' learning and well-being.

Aaron Panych was an instructional designer and member of the e-learning team at the Centre for Learning and Teaching, Dalhousie University, during this project. He is currently instructional designer and curriculum coordinator at Pacific Coast University for Workplace Health Sciences, British Columbia. 